\title{
Population ageing and inter-generational relation in the MENA: what role for social policy?
}

\author{
Mahmood Meskoub ${ }^{1 \star}$
}

\begin{abstract}
Declining fertility and rising life expectancy combined with migration are changing the demographic landscape of the MENA. Earlier high fertility however will ensure a growing population in the next 20-30 years. Family structure is also changing, it is becoming smaller and of nuclear type. The region has to manage a young age structure and a gradual ageing of population but with a potentially weaker traditional inter-generational support based on family, and varying and heterogeneous resource base and socio-economic structure of different countries. To maintain and improve inter-generational support within family and society in the MENA countries with large populations (such as Iran and Egypt) the most important challenges are poverty and vulnerability, unemployment, and development of long term plans for an ageing population. These are inter-connected objectives since reducing poverty and increasing current employment could provide individual and families with some resources to save and accumulate for old age. States in the region should put redistributive social polices in the areas of health, education and housing at the heart of a strategy of not only supporting family budget and resources to assist them in their inter-generational care, but also set up care and pension schemes for societal inter-generational support.
\end{abstract}

Keywords: Demographic transition, population ageing, inter-generational support, MENA, social policy.

DOI 10.1515/pophzn-2017-0005

Received: 17 April 2017, accepted 11 January 2018

\section{Introduction ${ }^{1}$}

The demographic landscape of the MENA region has been going through fundamental changes in the past few decades with very important implications for the economic and polity of the region. The main drivers of this demographic change have been declining fertility and migration. Earlier high fertility rates led to growth in the 'youth bulge' (the percentage of those of 15-24 years of age in population) in early $21^{\text {st }}$ century that

1 This paper draws on author's earlier works on population ageing (Messkoub, 1999), employment and poverty in the MENA (Messkoub, 2009), and ageing and inter-generational relationship (Messkoub, 2013). The author is grateful to three anonymous referees and the editors of the journal for their comments on an earlier draft. The remaining errors are, alas, mine! has since been on a declining trend, yet the number of young people is projected to increase in most MENA countries. But in Algeria, Iran and Tunisia the number of young people is projected to decrease. (Assaad and Roudi-Fahimi, 2007) All in all the gradual decline of fertility in the MENA is inevitably leading to population ageing. Another major demographic development in the region has been large-scale migrations both within and from outside the region, mostly in response to imbalances in the MENA labour markets.

Demographic transition provides predictable and important challenges to the economic and polity of a country. Decline in fertility and the gradual increase in the working age population opens a demographic window - availability of a young labour force - that if complemented by job creating investment could put the country on a self-sustaining path of economic

\footnotetext{
*Corresponding author: messkoub@iss.nl

${ }^{1}$ Erasmus Graduate School of Social Sciences and the Humanities
} 
growth and prosperity. This has been the experience of many of the newly industrialised countries in Asia and Latin America. On the other hand the gradual increase in the number and share of the elderly population will create new demands on the society. Whilst the resource base of a country is the starting point of any analysis of the long-term impact of the demographic transition, it is social and economic structure combined with the state policy and civil society engagement that determines how any society would meet the challenges of demographic transition.

These challenges are intrinsically inter-sectoral, both in terms of economic sectors of agriculture, industry and services as well as social sectors of health, social protection and care of the elderly. For a comprehensive approach we need to take note of the inter-sectoral issues, which would also help with the cost, and efficiency of service delivery and support to the target groups.

The backdrop to the changing demography of MENA is the complex set of countries in the region that have to develop social and economic policies in the next 30 years if they were to be prepared for the challenges of population ageing, migration and intergenerational support.

This paper is concerned with the social and economic implications of main demographic developments in the region focusing on social policy issues such as support for an increasing number of older people, inter-generational support and relationships which is contingent on household resources and gainful employment of the younger working age population; and social protection of the poor and vulnerable since poverty affects both the elderly and households who are expected to provide some care for them.

Such policies have to take note of the differing resource base of the MENA countries and the speed with which demographic changes are taking place and how certain developments like fertility decline are becoming a structural feature of the region, whilst other developments like international migration are market driven and could be subject to fast moving policy changes.

\section{Demographic transition and population ageing in the MENA}

The experience of demographic transition varies across the region, with different countries being at different stages of their transition. Earlier mortality decline followed by fertility decline have led to a gradual decline in the rate of population growth in the region that however varies across countries. (RoudiFahimi and Mederios, 2007) Yet earlier high growth of population has resulted in a young age structure (those in 15-24 age group constitute about 20 per cent of population in the region) that has ensured a growing population despite a declining fertility rate across the region. By 2050 most countries in the region are forecast to have anywhere between 1.3 to 1.7 times more people than in 2007. Life expectancy in most countries in the region has also increased and ranges between 70 and 73 years. (UN, 2013) The median age is increasing from 25 years in 2015 to 32 years in 2050 in the North African countries of MENA with the corresponding figures for the MENA countries located in the Western Asia being 29 and 37 (see Table 1).

At the same time we should expect an increase in the number of the elderly (those of 60 years of age and over) as well as an increase in their share in the population. Most recent UN population projections estimates that number of elderly will increase from 18 million in 2015 to 59 million in 2050 in the North Africa MENA countries and from 24 million to 96 million in the Western Asia MENA. (Ibid.) To complete the trends in ageing let us take a snap shot view of the percentage of elderly in total population in the region. Figure 1 shows that the percentage of the elderly in total population is increasing in the MENA region. In the North African MENA countries the percentage of elderly increases from 8 in 2015 to 16.7 in 2050, whilst in the Asian MENA countries the increase is from 5.4 in 2015 to 19.0 in 2050. In general, the richer the country the higher the percentage of the projected the elderly in total population. It is important to note that by 2050 the age structure of the richer MENA countries resembles those experienced currently by the highly developed countries which started their demographic transition earlier, at higher level of economic development and with more developed welfare and health policies. However, the MENA countries do have time on their side to develop the necessary welfare infrastructure in support of their elderly population in the future.

Changes to family formation and migration are the other notable demographic developments in the region. The age at first marriage has increased and so has the use of modern contraceptives that has led to a reduction in family size. The age at first marriage has increased in most MENA countries from 18-21 years 
Table 1. Population 60 years of age and over and Median Age, MENA region, 2015 and Projections 2030, 2050 (Source: Author's compilation based on UN (2015). Table A.III.1, p. 122.)

\begin{tabular}{|c|c|c|c|c|c|c|c|c|c|}
\hline \multirow{2}{*}{$\begin{array}{l}\text { Country/ } \\
\text { Region }\end{array}$} & \multicolumn{3}{|c|}{ Population age 60 \& over $(, 000)$} & \multicolumn{3}{|c|}{ Percentage aged 60 \& over } & \multicolumn{3}{|c|}{ Median Age (years) } \\
\hline & 2015 & 2030 & 2050 & 2015 & 2030 & 2050 & 2015 & 2030 & 2050 \\
\hline Northern Africa & 17,992 & 30,792 & 59,066 & 8.1 & 10.9 & 16.7 & 25.1 & 27.7 & 32.2 \\
\hline Algeria & 3,573 & 6,413 & 12,988 & 9.0 & 13.3 & 23.0 & 27.6 & 31.9 & 37.1 \\
\hline Egypt & 7,238 & 11,593 & 23,045 & 7.9 & 9.9 & 15.3 & 24.7 & 26.5 & 31.0 \\
\hline Libya & 439 & 894 & 1,823 & 7.0 & 12.0 & 21.8 & 27.5 & 31.8 & 38.4 \\
\hline Morocco & 3,317 & 6,012 & 10,239 & 9.6 & 15.1 & 23.4 & 28.0 & 33.1 & 38.6 \\
\hline Sudan & 2,081 & 3,633 & 7,406 & 5.2 & 6.4 & 9.2 & 19.4 & 22.3 & 26.2 \\
\hline Tunisia & 1,314 & 2,247 & 3,565 & 11.7 & 17.7 & 26.5 & 31.2 & 36.5 & 40.4 \\
\hline Asia & 24,395 & 46,235 & 95,766 & 7.6 & 11.8 & 20.4 & 26.3 & 30.7 & 36.6 \\
\hline Iran & 6,502 & 12,745 & 28,754 & 8.2 & 14.4 & 31.2 & 29.5 & 38.3 & 44.7 \\
\hline Bahrain & 53 & 178 & 432 & 3.9 & 10.8 & 23.7 & 30.3 & 35.6 & 42.2 \\
\hline Iraq & 1,817 & 3,162 & 7,402 & 5.0 & 5.8 & 8.8 & 19.3 & 21.1 & 24.3 \\
\hline Israel & 1,278 & 1,808 & 2,758 & 15.8 & 18.1 & 21.9 & 30.3 & 31.8 & 35.2 \\
\hline Jordan & 414 & 782 & 1,853 & 5.4 & 8.6 & 15.8 & 22.5 & 26.3 & 32.4 \\
\hline Kuwait & 133 & 442 & 1,188 & 3.4 & 8.9 & 20.1 & 31.0 & 33.9 & 37.8 \\
\hline Lebanon & 670 & 1,014 & 1,726 & 11.5 & 19.2 & 30.8 & 28.5 & 37.6 & 46.8 \\
\hline Oman & 196 & 494 & 1,434 & 4.4 & 9.4 & 24.5 & 29.0 & 34.2 & 40.1 \\
\hline Qatar & 51 & 221 & 633 & 2.3 & 7.9 & 19.8 & 30.7 & 34.0 & 41.0 \\
\hline Saudi Arabia & 1,582 & 4,324 & 9,610 & 5.0 & 11.1 & 20.9 & 28.3 & 32.3 & 38.2 \\
\hline Palestine & 211 & 421 & 1,014 & 4.5 & 6.2 & 10.4 & 19.3 & 22.3 & 27.4 \\
\hline Syria & 1,191 & 2,556 & 5,740 & 6.4 & 8.9 & 16.4 & 20.8 & 27.2 & 33.7 \\
\hline Turkey & 8,828 & 14,911 & 25,530 & 11.2 & 17.0 & 26.6 & 29.8 & 35.2 & 41.8 \\
\hline UAE & 215 & 1,238 & 3,004 & 2.3 & 11.3 & 23.5 & 33.3 & 36.6 & 43.4 \\
\hline Yemen & 1,254 & 1,939 & 4,688 & 4.7 & 5.3 & 9.9 & 19.3 & 23.0 & 29.6 \\
\hline
\end{tabular}

Note: Median ages for Asia are our calculations based on geometric means.

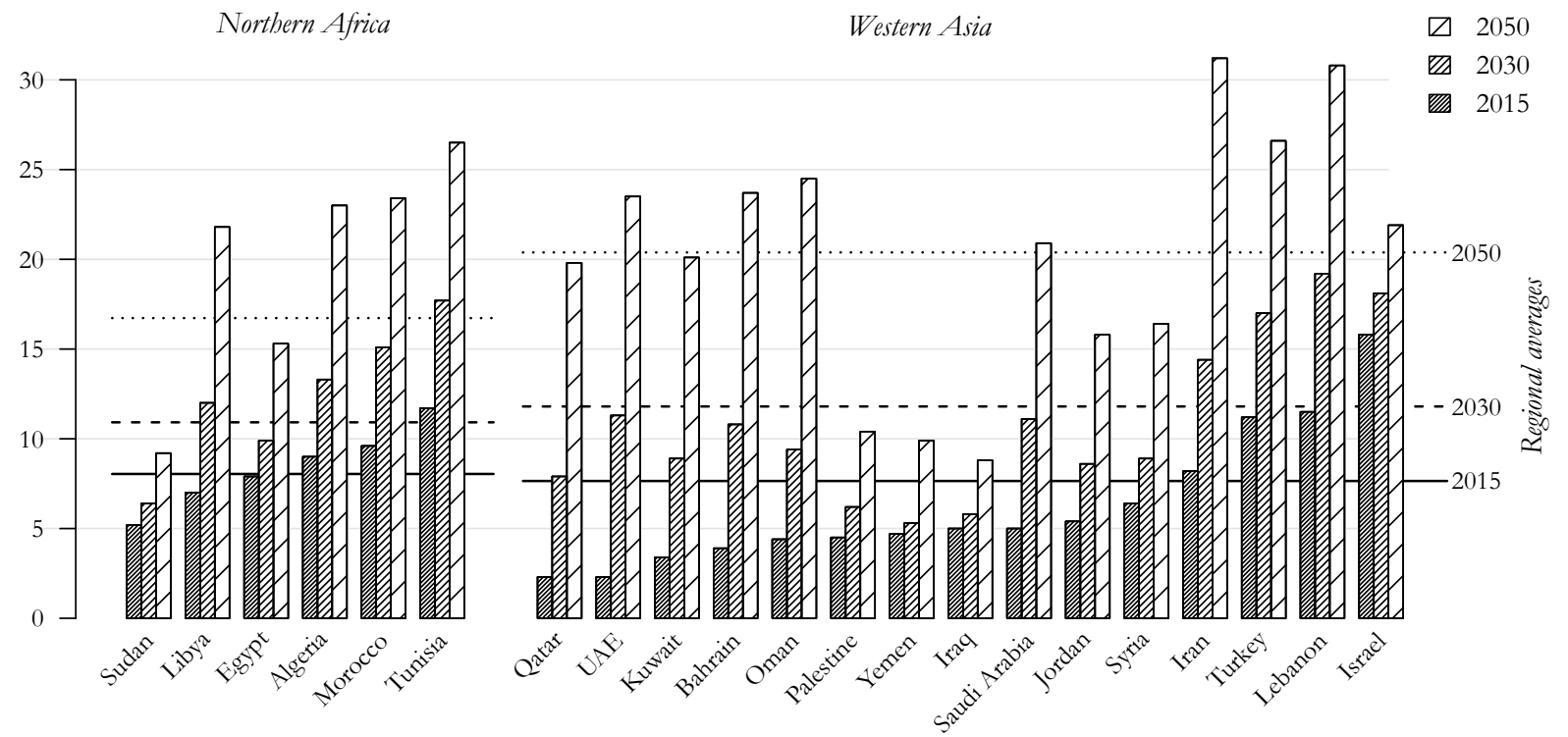

Figure 1. Percentage of population 60 years and over in total population, 2015, 2030 and 2050 in the MENA region. (Source: Table 1.) 
in the 1970 s to $22-25$ by the late 2000 . Another factor affecting fertility is that a large number of women are postponing marriage to their late 30s. (RoudiFahimi and Mederios, 2007, EU,2017) The increase in the average age and postponing of marriage has been attributed to the rise in the level of education of women, their autonomy and agency, as well as the rising cost of setting up a home, due to the property price inflation, high unemployment among the young people and high incidence of poverty among the working population. (Ibid.)

Family size in the region has decreased to 5.4 in urban and 6.1 in rural areas. Several factors may well account for this. The decrease in family size is associated with the increase in the education of the head of family. Moreover, family size is even smaller in nuclear families - 4.7 persons per nuclear family. Nuclear families comprise 85 per cent of all families in the region. A further development is the number of children per family. In urban areas there are 2.4 children per family and in rural areas 3, that again declines with the increase in the education of the head of family. In the foreseeable future the family size is going to be stable given the combined effects of declining mortality and fertility moving in the opposite direction. (See Table 2) These developments combined with the rising age of marriage and high youth unemployment ensures that there would be more adults at home, resulting in a stable dependency ratio. (Bongaart, 2001)

These changes are in line with the developments in other parts of the world. The trend towards smaller families in developing regions follows the pattern observed in the developed countries in the $19^{\text {th }}$ century, that has been attributed to adoption of some older methods family planning, urbanization (associated with lower fertility and mortality over time), 'modernisation' of life style and the move towards nuclear families, and above all the development of capitalism and its associated work patterns and family formation. (Bongaart, 2001, and Seccombe, 1983)

As far as migration is concerned, its size and direction crucially depends on the resource base of country and labour market conditions. The main direction of migration has been from poor MENA countries, the Indian sub-continent and the Far East to the rich MENA countries. In the MENA region as elsewhere in the world, national and international migration has always been part of the household strategy to improve the life chances of its members. Table 3 provides a snap shot view of migration in MENA. MENA countries can be divided into several groups based on their natural and human resources. (Cammett, et al., 2015) Almost all poor and labour abundant countries have sent large number of migrants to other countries, as indicated by the negative net migration figures. The reverse is true for labour deficit countries that have recorded positive net migration.

In concluding this section several observations are in order. Demographic changes are taking place in the MENA region at a very fast pace - families are getting smaller, more families are of nuclear type, and less children are borne. In resource poor, labour abundant countries poverty is a major problem for a large section of population. Migration has been an important part of family and individual strategy to cope with poverty and improving life chances for the family and individual.

The question is how these developments are going to affect the care and support of an ageing population. The answer lies in the balance between inter-

Table 2. Family size and number of children in developing regions by area of residence and education of head of family. (1980s)

\begin{tabular}{|c|c|c|c|c|c|c|}
\hline & & \multirow{2}{*}{$\begin{array}{l}\text { Residence } \\
\text { Urban }\end{array}$} & \multicolumn{4}{|c|}{ Head of family Education } \\
\hline & & & Rural & None & Primary & Secondary \\
\hline \multirow[t]{4}{*}{ Family Size } & Asia & 4.9 & 5.4 & 5.2 & 5.2 & 5.2 \\
\hline & L. America & 4.6 & 5.0 & 4.7 & 5 & 4.4 \\
\hline & Near E./N.Africa & 5.4 & 6.1 & 5.9 & 5.7 & 5.0 \\
\hline & S.S. Africa & 5.1 & 5.3 & 5.2 & 5.3 & 5.0 \\
\hline \multirow{4}{*}{$\begin{array}{l}\text { Number of } \\
\text { Children }\end{array}$} & Asia & 2.0 & 2.5 & 2.2 & 2.2 & 2.3 \\
\hline & L. America & 1.9 & 2.5 & 2.1 & 2.3 & 1.9 \\
\hline & Near E./N. Africa & 2.4 & 3.0 & 2.8 & 2.8 & 2.3 \\
\hline & S.S. Africa & 2.5 & 2.8 & 2.7 & 2.8 & 2.5 \\
\hline
\end{tabular}

Source: Adapted from Bongaarts (2001), table 4. 
generational support in terms of the demographic balance between generation within the family and society at large, and inter-generational support through the sharing and distribution of resources within family and society. In the final analysis it is the availability and distribution of resources within the family and in the society that determine how a society can manage demographic ageing.

Table 3. Net migration in MENA, 1995-2010.

\begin{tabular}{|c|c|c|c|}
\hline Country & $1995-2000$ & 2000-2005 & $2005-2010$ \\
\hline Bahrain & 19 & 25 & 448 \\
\hline Iran & 687 & 126 & -186 \\
\hline Iraq & -18 & -580 & -150 \\
\hline Israel & 245 & 103 & 274 \\
\hline Jordan & -188 & -94 & 203 \\
\hline Kuwait & 125 & 162 & 278 \\
\hline Lebanon & 0 & 100 & -13 \\
\hline Palestine & 70 & -190 & -90 \\
\hline Oman & -229 & -50 & 153 \\
\hline Qatar & 43 & 170 & 857 \\
\hline Saudi Arabia & -877 & 1726 & 1056 \\
\hline Syria & -130 & 548 & -56 \\
\hline Turkey & -150 & -100 & -50 \\
\hline UAE & 469 & 780 & 3077 \\
\hline Yemen & -100 & -100 & -135 \\
\hline Northern Africa & -1862 & -1667 & -1020 \\
\hline Algeria & -140 & -140 & -140 \\
\hline Egypt & -946 & -371 & -347 \\
\hline Libya & -20 & -20 & -20 \\
\hline Morocco & -500 & -614 & -675 \\
\hline Sudan & -227 & -532 & 135 \\
\hline Tunisia & -56 & -81 & -20 \\
\hline Western Sahara & 27 & 90 & 48 \\
\hline
\end{tabular}

Source: Adapted from: UN (2013) World Population Prospects: The 2010 Revision. New York: UN Population Division.

\section{Ageing and family: poverty and vulnerability}

Welfare in old age is based on combination of own resources - income from labour, assets (including own pension savings such as life insurance and annuity), family support in kind and in cash and institutional support from the state and employers in the form of state and work-based pensions, health cover and other benefits. The relative contribution of the above sources varies greatly in the MENA region, where family still is the main source of support for the majority of the elderly.

But do families have the resources to look after their older members? The simple answer is that they do not have sufficient resources, but continue to do so out of familial and humanitarian solidarity at a cost to themselves. Family support is becoming particularly taxing where as noted in the previous section family size is decreasing. Moreover, many families in the resource poor, labour abundant countries are too poor to comfortably manage the care of their elder members. The situation is no better among the poor in the resource rich MENA countries. The evidence comes from data on poverty and vulnerability.

The heterogeneity of the MENA is also reflected in the incidence of poverty and vulnerability in different countries. Using the headcount poverty measure of a-dollar-a-day (or more) poverty is rife in the labour abundant and resource poor countries. But poverty is also present in the large resource rich and industrializing countries of Iran and Algeria (Iqbal, 2005, Messkoub, 2008). The incidence of poverty however is very sensitive to the head count poverty rate. For example in Egypt it increases from less than 5 per cent of population at a-dollar-a-day to above 40 per cent at two-dollar-a-day. (Iqbal, 2005, p. 18) More recent data from other MENA countries also support the sensitivity of poverty to head count poverty rate. The World Bank data reveals that the percentage of people below poverty line increases dramatically from below 3 per cent at $\$ 1.90$ a day in Morocco and Tunisia to around 15 and 8 per cent, respectively, at $\$ 3.10$ a day. (World Bank, 2015) The other aspect of poverty is its regional spread. In all countries referred to in Iqbal's (2005) study, rural headcount poverty rates are higher in rural areas than in urban areas.

What these figures demonstrate is that a simple focus on head count poverty rates misses millions who are above the poverty line and very vulnerable to small shocks to their meager resource base. This suggests that some indicator of vulnerability should complement traditional headcount poverty rates when it comes to the assessment of inter-generational support and social policy design. Social policy measures in the MENA region in support of the elderly have to be focused on vulnerability of population rather than just on the poor.

An important aspect of vulnerability is low return to labour and precarious employment conditions. 
Employment as a major source of family income has come under great stress in recent years. In 2010, unemployment in the MENA region was about 10 per cent and the figure for women was 15 per cent. Youth unemployment is high in the region. In 2010, it stood at 27 per cent, with the figure being even higher among the educated youth. Female unemployment, in particular among the educated, is quite high: 40 per cent. Youth unemployment is not confined to the MENA region and many countries in Europe have record figures since the financial crisis of 2009. For example, Spain registered a youth unemployment rate of 46 per cent in 2012, Greece, 42 per cent and Cyprus 20 per cent. (ILO, 2012) But the distinguishing characteristic of youth unemployment in MENA is the fact that it has been high well before the financial crisis and is a structural feature of the labour market in the region. Job creation has hardly kept pace with a rising youth population as they enter the labour force. (Messkoub, 2009, Dhillon and Yousef, 2009, Sayer and Yousef, 2016) Both public and private sectors have been unable to create sufficient jobs for the growing number of youth entering the labour market, that most recent studies argue are due to the mismatch between demands for and supply of skilled labour as well as labour market regulations. (Sayer and Yousef, 2016) These studies call, inter alia, for changes in the educational systems that put more value on acquisition of credentials/degrees than skill development, whilst reforming labour market regulations in order to facilitate hiring rather than just making it easier to lay people off, and by providing incentive structure to boost demand for labour by the private sector. (Ibid.,) However, such reforms take time to implement whilst there are the pressing needs of the poor unemployed people and the working poor.

In absence of no or very meager unemployment benefit in most MENA countries poor people cannot 'afford' to be unemployed. The working poor are a sizable proportion of the working population. In late 1990s working poor accounted for 12 per cent of working population in Tunisia, with the figure rising to 30 per cent in Algeria, and staggering figures of 71 per cent in Egypt and 74 per cent in Yemen. (See table 4) The reasons for why people remain poor despite their hard work are varied and complex. Unequal distribution of assets and power play an important role in holding back the working poor from claiming their just and fair share of what they produce. Many small farmers do not have access to sufficient land or other agricultural inputs to improve their productivity.
The self-employed people in urban areas often lack the resources to expand and improve their operations. In short low productivity is at the heart of low return to labour in many sectors. At the same time weak trade unions and poor implementation of labour laws do not empower workers to ask for higher wages and better conditions. Absence of or low minimum wage is another reason for the low return to labour in many countries.

Table 4. Working Poor as a proportion of working population in selected MENA countries (late 1990s)

\begin{tabular}{ll}
\hline Country & $\begin{array}{l}\text { Working Poor } \\
\text { \% }\end{array}$ \\
\hline Yemen & 74 \\
Egypt & 71 \\
Algeria & 30 \\
Morocco & 23 \\
Jordan & 13 \\
Tunisia & 12 \\
\hline
\end{tabular}

Source: ILO (2012)

The importance of employment and secure return to labour (whether it is termed a decent wage or a living income) cannot be over-estimated. What is needed above all is an employment policy that puts the emphasis on strengthening the growthemployment nexus by promoting job creation and improving the access of the poor to such jobs. At the same time more targeted poverty reduction policies are needed that should not only improve the income earning opportunities of the poor but also raise their incomes. Anti-poverty policies should also be put in place to provide support for a large number of people who are just above poverty line and thus vulnerable to poverty in case of minor deterioration in the macroeconomic conditions or their poverty stricken household economy. MENA countries that have been successful in tackling poverty and vulnerability have relied on a range of policies: macroeconomic stability, pro-poor short-term employment policies (through labour intensive public work projects and by focusing on sectors where poor are concentrated) and improving opportunities for the poor in order that they would benefit from employment growth (improving 'inerrability' of the poor). ${ }^{2}$ These countries

2 For a detailed discussion of the 'growth-poverty-nexus' see Messkoub (2009) 
have also improved the health, education, housing and sanitary conditions of the poor by increasing social expenditure, and by putting in place income support measures and maintaining subsidies on goods consumed by the poor. Finally successful anti-poverty policies have also improved the poors' access to financial (through micro finance) and other productive resources such as land.

But it is the structural reasons for low return to labour that should be of most concern to policy makers. Unequal distribution of land, low skills, low capital investment, inefficient and often outdated technology will all lead to low productivity and low return. The financial and banking sector is also not geared to the needs of the small producers and the selfemployed poor people. The micro-credit 'revolution' that was supposed to fill this gap has hardly changed the fortune of the great majority of the poor. What is needed is to tackle the problems of unequal distribution of power and assets that requires some fundamental political changes and more commitment by the state to improve education and skill levels as well as helping to upgrade technology in agriculture and industry.

It should be clear that most families do not have adequate resources to meet their needs and provide adequate inter-generational support. Given the chronic and structural poverty in the labour abundant and resource poor countries inter-generational support has to go beyond families and take the broader perspective of societal inter-generational relations. In the labour deficit and resource rich countries the issue of inter-generational support within families poses several problems that again calls for a societal approach to inter-generational relationship. The first is the issue of income inequality in these countries. Only the small and very rich oil and gas producing countries can maintain sufficiently high-income transfers to, as well as providing high level of health and educational services, for their nationals to ensure adequate inter-generational support by families. In most of the larger oil exporting countries (e.g. Iran and Algeria) inequality in the distribution of income and assets, unemployment and inadequate public services have for long been the main reasons for public discontent.

Lack of or inadequate democratic structure and governance to ensure accountability, participation and transparency have also seriously limited the voice and the negotiating power of the majority of population in MENA. Finally, there is the all important issue of the rights of international migrants who have been of critical importance to the economy of labour deficit countries, and would become even more important in the future as population ages in these countries. It is no exaggeration to state that the inter-generational support in areas of health, education, housing and care, to name but a few, in labour deficit countries cannot be maintained without the availability of migrant labour. It is in this context that we turn to societal inter-generational support and social policy.

\section{Social policy, families and inter-generational support}

At micro-level family is the main channel through which various types of inter-generational support are provided, that contributes to production and re-production of labour at micro and macro levels. Families however are not homogenous and are divided along social and economic lines that determine their capacity to provide inter-generational support. As noted earlier given the high incidence of poverty in many of the MENA countries and inadequacy of family resources there is a need for social policy measures that would supplement family resources and support the broad developmental agenda and ensure societal inter-generational support.

The most basic objective of any state intervention is to maintain and increase families' resource base. In this context state intervention for inter-generational support could be linked to market for: goods (e.g. provision of necessities such as health, education, housing and basic food stuff), labour (e.g. job creation and labour issues) and money (e.g. provision of credit for businesses).

More specifically family budget constraint will be improved by first de-commodifying (through regulation and intervention in the market) the basic necessities of life. De-commodification does not necessarily mean free provision of goods and services. It could take different forms like rent control, subsidized medicine and staple food, free primary 
schools, free vaccination, etc. ${ }^{3}$ Second, by improving the human capital of family through improved health and education, employability and income earning opportunities of families will increase. Third, by maintaining labour demand through job creation by private and public sector and increasing labour force participation of women families will have more secure earning opportunities through employment.

Implementing the above policies would depend on the resource base of different countries. The resource rich and labour short countries obviously have an advantage over the others by having large foreign exchange reserves and no financial constraint to finance universal welfare programmes. The issue of inter-generational support is not a problem, neither at family nor at national level for these countries. Despite the existence of some youth unemployment in these countries, family resources and state spending are sufficient to maintain good standard of living for the young. But problems of these countries is rooted in their demography - they are short of labour to maintain and develop their economies almost in all sectors and skill levels, a gap that is filled by immigrant labour. With investment in education and skills in these countries, it is hoped that the shortage of skilled labour may somewhat be lessened but in other areas labour shortages will continue, particularly in the care, construction and service sector. It would also be expected that demographic transition and population ageing will increase the need for inter-generational support, that with the most likely increase in the labour force participation of women, would generate a demand for migrant labour. In short inter-generational support in resource rich, labour deficit countries will require a stable and steady flow of migrants.

Whether this demand for migrant labour will be fulfilled depends on the demographic situation and economic development in the labour abundant MENA and the Asian countries (e.g. Bangladesh, Nepal, India, Philippines) that have been sending migrants to the MENA region for decades. However, demographic transition is already underway in many of the emigration countries that if combined with their

3 De-commodification however has to be put in the context of the existing subsidies some of which like those to fuel and energy may well benefit the higher income groups. There are also implicit subsidies low exchange rate and low interest rates that again could benefit higher income groups more than others. The reform of such subsidy structure has to be combined with decommodification/subsidy structure that would benefit the lower income groups. steady economic development would increase the demand for labour and improve pay and conditions. That in trun would lower the propensity to migrate to the labour deficit MENA countries. To ensure a steady flow, the migrant receiving countries have to change their migration policy that would not only improve pay and conditions for the low skill migrants but also introduce some flexibility in the labour market. The current 'guardianship' ('kefalat') system that ties the immigrant to the sponsoring or 'guardian' ('kafil') employer has led to labour market segmentation (defined as a market divided by non-competing groups) in labour deficit countries, where citizens and nationals as well as high skilled migrant workers have far more rights and enjoy better living standards than the low skilled migrants working in construction, service and other sectors.

What is needed is an integrated labour market where labour law and rights could be applied to all in order to improve pay and conditions of immigrant labour. This would improve the flexibility in the labour market and stabilise the migrant labour and bring the labour deficit countries closer to some of the best practices in other countries. Moreover, the labour deficit countries should also plan for permanent immigration in order to solve their long-term labour imbalance. It is highly unlikely that the labour deficit countries can close the gap between their labour demand and national labour supply in the near future considering their demographics. One of the best policies in the area of immigration is admitting migrants on the basis of skill shortages that would give the right to enter and reside temporarily that could in due course lead to long-term residency.

The next group of countries to consider is resource rich and labour abundant countries. These countries have experienced improved human development for their nationals through basic programme in the areas of health, education, subsidized food, etc. The scope and scale of such provisions, however, vary greatly across different countries, that is dependent on high oil prices. Ensuring that families can fulfill their inter-generational support in resource rich labour abundant countries governments have to maintain the real income of families by controlling inflation and cost of two major items of expenditure - housing and curative health care. This calls for prudent expenditure of the oil money in the country to avoid inflationary pressure, and partial de-commodification of health and housing. Another major concern in the medium term is high youth unemployment in these 
countries that requires active job creation policies, involving both public and private sector.

Resource poor and labour abundant countries face many more hurdles than the other groups. Their human development varies greatly across social classes, with the richer classes enjoying better standard of living and higher human development. These countries face chronic foreign exchange constraints and fiscal problems that would limit their policy space to carry out much needed social policy measures in areas of health and education. Like elsewhere in the MENA region, they also suffer from high youth unemployment. How have families in these countries coped with their low living standards, poverty and vulnerability?

As noted earlier, migration to richer countries in the region and beyond has helped to improve living standards for migrant sending families. Remittances have been an important contributor to family income and a source of foreign exchange for the government. Considering the level of poverty and high unemployment in the migrant sending countries families have limited scope for inter-generational support, without relying on state subsidies to basic foodstuff, education and health. Social policy measures in these countries to ensure family based and societal inter-generational support are no different from the resource rich and labour abundant countries, except that their needs are bigger and their finances more limited.

However, states could still do a lot in the resource poor countries by focusing on some key areas like universal and free preventive and primary health care, as well as school level education, and de-commodification through intervention in the market for curative health care, housing and higher education.

Job creation and job protection should also be on the agenda. Whilst state in the resource poor countries have a lot less economic power than in the resource rich countries, they nevertheless can contribute to job creation by providing support to the private sector through appropriate tax and subsidy policies, and by training and educating the work force to meet the skill needs of the private sector.

An important legacy of the MENA is the historical, cultural and linguistic links in the region. For centuries and well before the emergence of the nation state, people in the MENA region interacted through trade and migration. Common religions and languages should also help to bring the MENA region together. These links do give a regional dimension to the issue of inter-generational support. Migration and remittance flows demonstrate that inter-generational support already relies on regional economic linkages.

Yet, by all accounts, the region is very poorly integrated. Regional trade accounts for less than 10 percent of total trade in the Arab MENA, with the Maghreb countries having the lowest share of intraregional non-oil merchandise trade. Low regional integration, according some studies, has led to the potential loss of 1-2 per cent growth of GDP. Higher GDP growth is particularly important for creating jobs for the 20 million or so unemployed people in the region and for the new comers who enter the labour market at an annual rate of 3.4 per cent. (World Bank, 2013, see also Hakimian and Nugent, 2004)

Strengthening existing regional links in relation to migration and labour mobility could contribute to inter-generational support. This could be helped by the integration of labour market across the region, initially by reducing regulation in hiring nonnationals, and by de-politicising migration of labour. The future generations are going to live in the same region and regional economic cooperation is needed if inter-generational support were to continue.

\section{Conclusion}

Demographic map of the MENA is changing fast. The region is in the early stages of a demographic transition. On the one hand earlier high fertility has resulted in the current youth bulge. On the other, gradual fertility decline and lower mortality is leading to an ageing population. A youth bulge provides the region with a demographic window if the young and increasingly educated labour force of MENA were to be utilized productively. The current high youth unemployment in the region reveals that job creation and labour demand has lagged far behind the labour supply in the region; that in part is due to the low employment elasticities of different sectors.

This overall picture however masks great variation across the region. Youth unemployment in labour abundant resource poor countries is matched by labour shortages in some of the resource rich countries that have to rely on migrant labour to fulfill their labour demand. It is in this context that regional and international migration has to enter the demographic debate and anti-poverty strategies in the region.

Demographic transition also involves a gradual 
increase in the number and share of the elderly in the population in the coming years. Population ageing is not as urgent a challenge as youth unemployment, yet given its certainty and the fact that the family has been the main institution of inter-generational support it is important to refine social policy measures that would improve family's budget constraint and its ability to manage intra-family transfer and inter-generational support that changes through the life cycle of a family. It is worth bearing in mind that the youth who are unemployed or in education are currently supported by parents who will be the elderly member of the family in the future.

However, there is no guarantee that intergenerational support will necessarily extend to the care of the future elderly. Migration and changing family structure away from multi-generational households to nuclear families, as elsewhere in the world, have weakened inter-generational support within families. That is why pension policies and long term care for the 'very old' have been on the agenda in the debate on ageing. Pensions in the MENA countries are generally a prerogative of state employees and larger companies in the formal sector.

Development of a two-tier pension scheme could help with vulnerability in old age, especially for those in the informal sector and those who are not in the market-based labour force, yet are an important and indispensable source of labour in the non-market and household based work. The latter group would cover the great majority of the women who in the MENA have one of the lowest labour force participation rates in the world and therefore excluded from most of the labour-market based social protection schemes. Tier one could be designed as a pay-as-you go tax or social insurance contribution based scheme that is open to all residents, irrespective of citizenship rights, that in part will also provide some old age protection to the immigrant workers. Tier two could be a fully funded contribution based scheme that again should be open to all residents irrespective of citizenship status. Tier one is effectively a social protection floor for the old age. Tier two provides extra support in old age and could be based on compulsory membership and contribution, or could be combined with tax incentives to encourage membership. The long established assumption of myopia and poor planning for old age underpins the 'coercive' logic of nudging people to enroll in tier two type pension schemes.

Policy makers in the MENA need to put social policy at the heart of any strategy to manage long-term impacts of demographic transition. The region does not have the extensive social and economic structures of the richer developed countries, which went through their demographic transition at a slower pace and with more resources. Yet the region has at least a 20-year window to develop and implement policies to manage its demographic transition.

\section{References}

Auer, P. and Islam, R. (2006). Economic Growth, Employment, Competitiveness, and Labour Market Institutions. In: XX Global Competitiveness Report 2006-07. Basingstoke, UK: Palgrave Macmillan: The World Economic Forum., pp. 105-116.

Bongaarts, J. (2001). Household Size and Composition in the Developing World. New York: Population Council, report no. 144.

Brandsma, J. and Bajourjee, D. (2004). Microfinance in the Arab World. New York: U.N. Capital Development Fund.

Broude, T. (2010). 'Regional Economic Integration in the Middle East and North Africa: A Primer,' in C. Herrmann and J.P. Terhechte (Eds), European Yearbook of International Economic Law, European Yearbook of International Economic Law. Berlin Heidelberg: Springer-Verlag. Cammett, M., Diwan, I. Richards, A., Waterbury, J. (2015) A Political Economy of the Middle East. Boulder, Colorado, US: Westview Press. Fourth Edition .

Cole, J. and Durham, D. (2007). Generation and Globalization: Youth, Age and Family in the New World Economy. Bloomington and Indianapolis, US: Indiana University Press.

Dhillon, N. and Yousef, T. (Eds) (2009). Generation in Waiting: The Unfulfilled Promise of Young People in the Middle East. Washington, D.C.: Brookings Institution.

EU (2017). Eurostat - Archive:Youth statistics - North Africa and Eastern Mediterranean.

http://ec.europa.eu/eurostat/statistics- explained/index.php/ Archive:Youth_statistics_-_North_Africa_and_Eastern_ Mediterranean. Accessed: 10 March 2017

Hakimian, H. and Nuggent, J. B. (Eds) 2004. Trade Policy and Economic Integration in the Middle East and North Africa: Economic Boundaries in Flux. London and New York: Routledge and Curzon.

ILO (2005). World Employment Report 2004-05: Employment, Productivity and Poverty. Geneva: ILO.

ILO (2006). Employment Poverty Linkages and Policies for Pro-poor Growth in Jordan (1990-2003). Geneva: ILO. Second Draft. Mimeo (restricted document)

ILO (2009). Key Indicators of the Labour Market (KILM). Fifth edition. Geneva: ILO.

ILO (2012). Global Employment Trends for Youth 2012. Geneva: ILO. http://www.ilo.org/wcmsp5/groups/public/--dgreports/---dcomm/documents/publication/wcms_180976. pdf Accessed 20 May 2013.

ILO (2015). Synthesis review of ILO experience in youth and women's employment in the MENA region: Summary 
version ILO Regional Office for Arab States - Beirut: ILO. http://www.ilo.org/wcmsp5/groups/public/---arabstates/--ro-Beirut/documents/publication/wcms_432593.pdf Accessed 10 March 2017

Iqbal, F. (2005). Sustaining Gains in Poverty Reduction and Human Development in the Middle East and North Africa. Washington, D.C.: World Bank.

Islam, I. (2009). The Global Economic Crisis and Developing Countries: Transmission Channels, Fiscal and Policy Space and the Design of National Responses. Geneva: ILO, Employment Sector, Working Paper No. 36.

Islam, R. (2004). The Nexus of Economic growth, Employment and Poverty Reduction: An Empirical Analysis. Geneva: ILO.

Karshenas, M. and Moghadam. V. (Eds) (2006). Social Policy in the Middle East and North Africa. Basingstoke, UK: Palgrave Macmillan, and Geneva: UN Research Institute for Social Development.

McKinley, T. and Mehran, F. (2006). Strengthening the Employment Impact of an MDG-Based Development Strategy for Yemen. Brazil: UNDP, International Poverty Centre, Country Study No. 4, September.

MENAFN, (2010). http://www.menafn.com/qn_news_story_s. asp?StoryId=1093365023 Accessed 8 August 2010.

Messkoub, M. (1999). 'Crisis of Ageing in Less Developed Countries: Too Much Consumption or Too little Production.' Development and Change. Vol. 30, No. 2, April.

Messkoub, M. (2006). 'Constitutionalism, Modernization and Islamization: A

Political Economy of Social Policy in Iran. In: M. Karshenas and V. Moghadam (Eds) (2006). Social Policy in the Middle East and North Africa. Basingstoke, UK: Palgrave

Macmillan, and Geneva: UN Research Institute for Social Development.

Messkoub, M. (2006). 'Social Policy in Iran in the $20^{\text {th }}$ Century', Iranian Studies, 39(2)

Messkoub, M. (2008). Social Policy in Iran: Islamic or Secular? Policy World. Spring. Published by the British Social Policy Association.

Messkoub, M. (2008). Economic Growth, Employment and Poverty in the Middle East and North Africa. Geneva: ILO Working Paper Series, No. 19.

Messkoub, M. (2011). 'Crisis, Employment and Poverty in the Middle East and North Africa,' in P.A.G. van Bergeijk, R. van der Hoeven and A. de Haan (Eds). The Financial Crisis and Developing Countries. Cheltenham, UK: E. Elgar Publishers.

Miniesy, R.S., Nugent, J., Yousef, T.M. (2004). 'Intra-Regional Trade in the Middle East: Past Performance and Future Potential', in H. Hakimian and J. Nuggent (eds.), 2004. Trade Policy and Economic Integration in the Middle East and North Africa: Economic Boundaries in Flux. London and New York: Routledge and Curzon.

Mirkin, B. (2013). Arab Spring: Demographics in a region in transition. Arab Human Development Report Research Paper Series. New York: UNDP.

Osmani, S.R. (2003). Exploring the Employment nexus: Topics in Employment and Poverty. New York: UNDP and Geneva: ILO.

Roudi-Fahimi, F. and Mederios, M. (2007). Challenges and Opportunities - The Population of the Middle East and North Africa. Population Reference Bureau
Population Bulletin, Vol. 62, No. 2, June. Washington, DC: Population Reference Bureau. Assaad, R. and Roudi-Fahimi, F. (2007). Youth in the Middle East and North Africa: Demographic Opportunity or Challenge? Washington, DC: Population Reference Bureau.

Salehi-Isfahani, Dj. (2010). Human Development in the Middle East and North Africa UNDP Human Development Research Paper 2010/26. New York: UNDP

Sayre, E. A. and Yousef, T. M. (2016). Young Generation Awakening: Economics, Society, and Policy on the Eve of the Arab Spring. New York: OUP.

Seccombe, W. (1983). 'Marxim and demography,' New Left Review, No. 137.

Subbarao, K. (2003). Systemic Shocks and Social Protection: Role and Effectiveness of Public Works Programs. Washington, D.C.: World Bank, Social Protection Discussion Paper Series.

Sundaram, K. and Tendulka, S.D. (2002). The working poor in India: Employment-Poverty linkages and Employment Policy Options. Geneva: ILO.

Tzannatos, Z. (2009). The Global Financial, Economic and Social Crisis and the Arab Countries: a Review of the Evidence and Policies for Employment Creation and Social Protection. Beirut: ILO Regional Office for Arab States.

UN (2013) World Population Prospects: The 2010 Revision. New York: UN Population Division.

UN (2015). World Population Prospects: The 2015 Revision. New York: UN Population Division. ESA/P/WP.241. https:// esa.un.org/unpd/wpp/publications/files/key_findings_ wpp_2015.pdf. Accessed: 18 March 2017

UNDP (2012). Arab Development Report 2011. Cairo: UNDP. UNIDO (United Nations Industrial Development Organization) (2001). Integrating SME subglobal value chains: Towards partnership for development. Vienna: UNIDO.

UNFPA (2009). Family support network and population ageing. New York: UNFPA. http://www.unfpa.org/sites/default/ files/pub-pdf/family_support_networks2009.pdf Accessed, 18 March 2017.

World Bank (2009). 2008 Economic Development and Prospects: Regional Integration for Global Competitiveness. Middle East and North Africa Region. Washington DC: IBRD.

World Bank (2011). World Development Report, 2011. Washington DC: IBRD.

World Bank (2013). 'Trade Integration in the Middle East and North Africa'. http://web.worldbank.org/WBSITE/ EXTERNAL/COUNTRIES/MENAEXT/EXTMNAREGTOPPOVR ED/0,,contentMDK:22492441 pagePK:34004173 piPK:34003 707 theSitePK:497110,00.html. Accessed: 1 August 2013.

World Bank (2015). Poverty and Equity Data Base. http:// povertydata.worldbank.org/poverty/region/MNA Accessed, 10 March 2017

Yount, K.M., Cunningham, S., Agree, E., Engelman, M. (2009). Gender, generation and economic transfers in Ismailia, Egypt. In: UNFPA (2009) Family support network and population ageing, pp. 39 - 47. New York: UNFPA.

Zakaria, K. (2009) Notices concerning elder's patronage in the Arab countries. In: UNFPA (2009) Family support network and population ageing, pp. $53-56$. New York: UNFPA. 